\title{
Characteristics of Patellofemoral Measurement in Indonesian Population Using Magnetic Resonance Imaging
}

\author{
Sholahuddin Rhatomy ${ }^{1 *}$, Kurniawan Silalahi ${ }^{2}$, Anggaditya Putra ${ }^{3}$, Nolli Kresonni ${ }^{4}$ \\ ${ }^{1}$ Department of Orthopaedics and Traumatology, Dr. Soeradji Tirtonegoro General Hospital, Klaten, Indonesia/Faculty of \\ Medicine, Public Health and Nursing, Universitas Gadjah Mada, Yogyakarta, Indonesia; ${ }^{2}$ Department of Orthopaedics and \\ Traumatology, Putri Hijau Army Hospital, Medan, Indonesia; ${ }^{3}$ Department of Orthopaedics and Traumatology, Fatmawati \\ General Hospital, Jakarta, Indonesia; ${ }^{4}$ Department of Radiology, Indriati Hospital, Sukoharjo, Indonesia
}

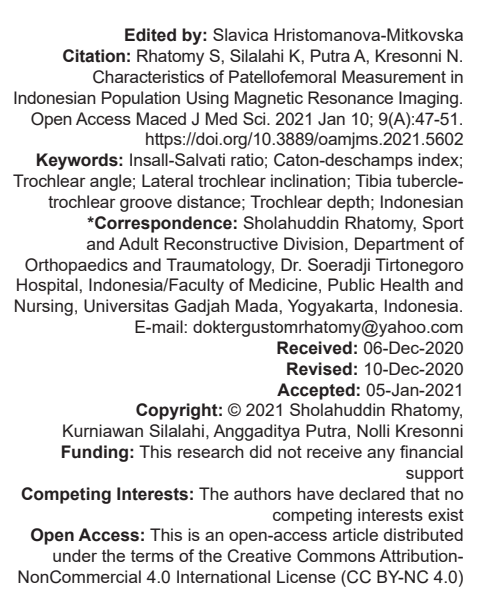

Introduction

The patellofemoral joint (PFJ) is a unique complex joint formed by articulation of the patella and the femoral trochlea [1]. The bony morphology of the joint, the quadriceps/patella tendon, and the capsuloligamentous attachments together play a role in the stability of the PFJ [1], [2]. It has multiple contacting pressure points that are influenced by the degree of knee flexion [3].

Such complex structures will eventually suffer from a wide range of problems. First and foremost, there is commonly patellofemoral instability with incidence reaching 5.8/100,000 population [1]. The next common complaint that may arise is patellofemoral pain that constitutes almost $25 \%$ of knee problems [4]. Both of these problems are correlated to each other but the exact pathomechanisms are not fully understood yet because there are so many factors affecting these pathologies. One concern is improper alignment which causes dysfunction of the patellofemoral joint that can lead to abnormal contact pressures, which may explain some of the patients' symptoms [5]

Many radiological studies have been conducted rigorously by an abundance of authors to better understand the anatomy and biomechanics of the PFJ and its pathologies. Imaging modalities are useful for characterization of patellar malalignment, maltracking, underlying morphologic abnormalities, and stabilizing soft-tissue injuries [6].

Four factors which are relevant in knees with symptomatic patellar instability are trochlear dysplasia, quadriceps dysplasia, patella alta, and the tibial tuberosity-trochlear groove (TT-TG) distance [7], [8], [9]. Patellofemoral dysplasia is a major predisposing factor for instability of the PFJ. The biomechanical effects of patellofemoral dysplasia, with different anatomical and demographic risk factors have been suggested in an attempt to identify the recurrent dislocations [3]. However, it is still presenting an extremely challenging condition to 
manage. Therefore, a comprehensive evaluation of all the radiographic parameters can help the clinicians to assess their patients.

Magnetic resonance imaging (MRI) evaluation of the knee forms an integral part of investigation of patients with knee pain or knee instability because it can provide useful information about the bony morphology of the femur and patella as well as the condition of the articular cartilage [9], [10]. MRI assessments can evaluate some of the factors as measurable parameters such as Insall-Salvati ratio, Caton-Deschamps index, trochlear depth, lateral trochlear inclination, TT-TG distance, and trochlear (Sulcus) angle.

Most of studies relating to PJF and its pathologies were conducted in western countries. We are aware that each country has its own anatomical uniqueness due to race and cultural differences. As the fourth most populated country in the world, Indonesia has many patients with knee pain. But to date, Indonesia does not have any study regarding this important matter. This study aimed to describe the characteristics of patella femoral measurements in an Indonesian population using MRI.

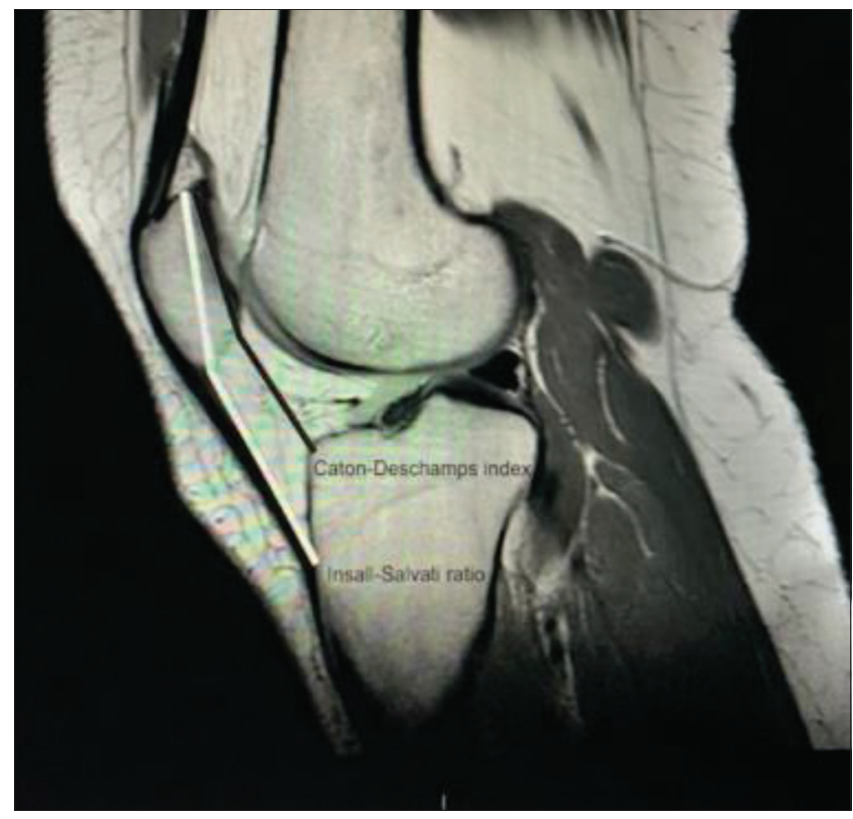

Figure 1: Insall-Salvati ratio and Caton-Deschamps index measurements

\section{Materials and Methods}

This descriptive total sampling study was conducted from May 2019 to August 2020. Human research ethics approval was obtained from the local institutional review board before the initiation of any study activities. Patients were included of this study if they are healthy with age 18-65 years old and
Indonesian people. We consecutively collected the MRI of normal knees of the right side. The exclusion criteria were the patients with the histories of knee abnormalities, knee disease, or had previous knee surgery.

\section{Outcome measures}

The parameters of the measurements in this study included Insall-Salvati ratio, Caton-Deschamps index (Figure 1), trochlear angle (Figure 2), lateral trochlear inclination (Figure 3), trochlear depth (Figure 4), and TT- TG distance (Figure 5). Then, the mean results of the measurements were compared with the international normal values.

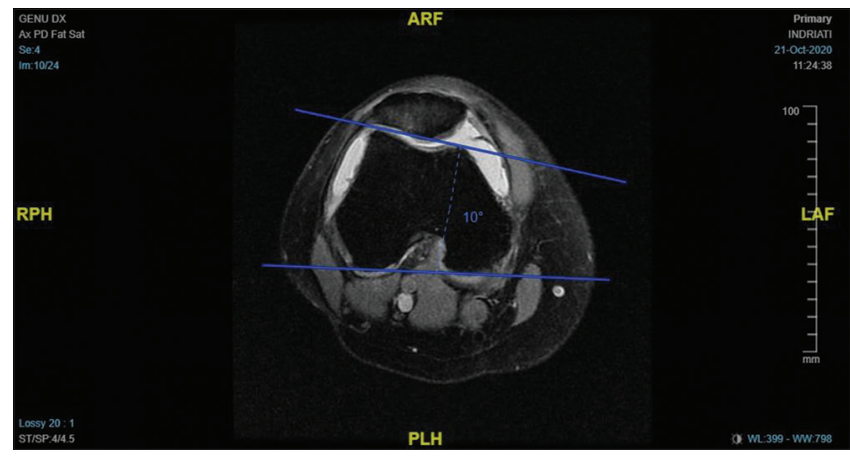

Figure 2: Trochlear angle

Descriptive statistics were generated for demographic data. Repeated measures $t$ tests were used to compare values. All analyses were performed using SPSS 26.0 (IBM SPSS, Atlanta, GA). Statistical tests were considered significant at $a=0.001$.

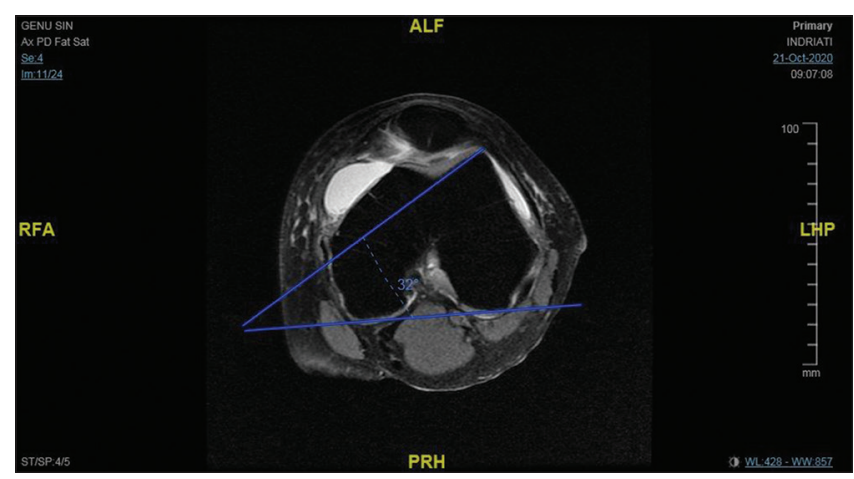

Figure 3: Lateral trochlear inclination angle

\section{Results}

A total of 100 normal knees MRI scan from patients consisting of 54 (54\%) males and 46 (46\%) females were assessed in this study, with an average age of $35.09 \pm 12.77(19-60)$ years old. The average body mass index (BMI) at the time of assessment 


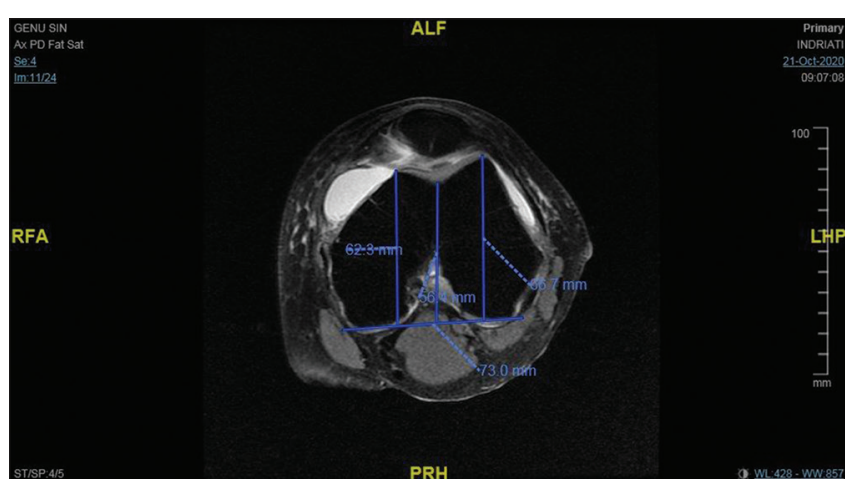

Figure 4: Trochlear depth

was $28.07 \pm 3.0(22-34)$ (Table 1$)$. The composition of the subjects based on ethnicity was mostly Javanese $(66 \%)$, Sundanese $(12 \%)$, Minangkabau $(7 \%)$, Madura $(4 \%)$, and the others $(11 \%)$ (Table 2 and Figure 6).

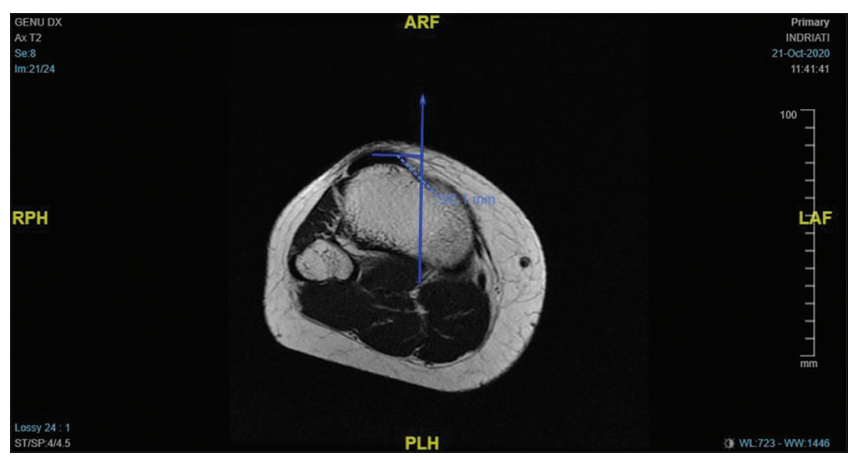

Figure 5: TT-TG

The mean of Insall-Salvati ratio was $1.09 \pm 0.17$ (0.49-1.60). The mean of Caton-Deschamps index was

Table 1: Demographic data of the study population

\begin{tabular}{ll}
\hline Age & $35.09 \pm 12.77(19-60)$ \\
Gender & Male: 54. Female:46 \\
Body mass index & $28.07 \pm 3.0(22-34)$ \\
\hline
\end{tabular}

$0.97 \pm 0.16(0.62-1.64)$. The mean of trochlear angle was $138.97 \pm 119.7\left(122^{\circ}-160^{\circ}\right)$. The mean of lateral trochlear inclination was $20.37 \pm 4.56$ (11.0 30.6). The mean of TT-TG distance was $13.76 \pm 5.86$ (4.9-41), and the mean of trochlear depth was $5.18 \pm$ 1.87 (1.05-8.6). Those values were within the range of normal international values (Table 3 ).

Table 2: Composition of subjects

\begin{tabular}{lll}
\hline Ethnicity & Number & Percentage \\
\hline Java & 66 & 66 \\
Sundanese & 12 & 12 \\
Madura & 4 & 4 \\
Minangkabau & 7 & 7 \\
Others & 11 & 11 \\
\hline
\end{tabular}

There were no significant differences in the comparison between males and females (Table 4). Comparison of our results with other published studies showed that the TT-TG of Indonesian people was higher than other Asian, Europe, and American countries (Table 5).

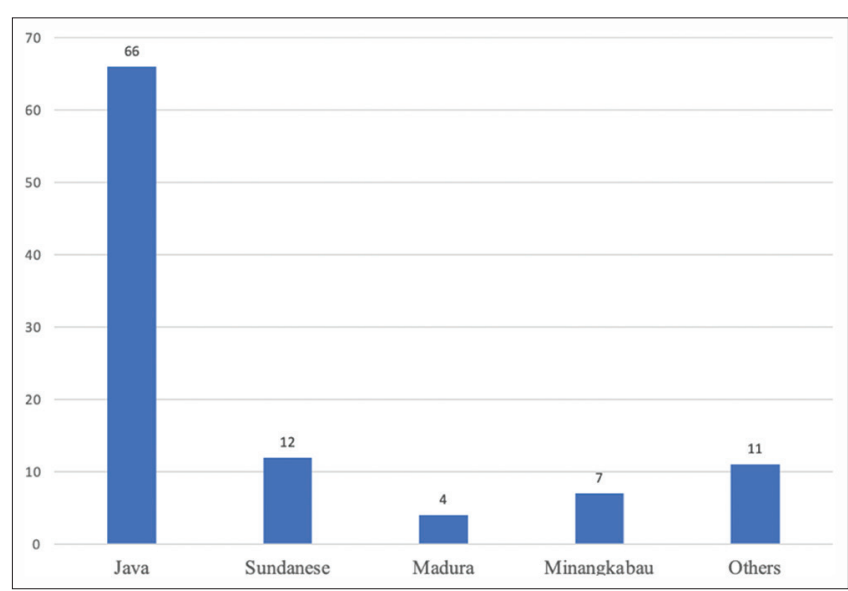

Figure 6: Composition of subjects

\section{Discussion}

The biomechanical effects of patellofemoral dysplasia on patellar stability have not been fully investigated. Furthermore, different anatomic and demographic risk factors have been suggested in attempts to identify the sources of some of the problems.

Table 3: Measured patellofemoral indices

\begin{tabular}{lll}
\hline Parameters & $\begin{array}{l}\text { International normal } \\
\text { value }\end{array}$ & $\begin{array}{l}\text { Result of measurement } \\
\text { (Mean } \pm \text { SD, Range) }\end{array}$ \\
\hline Insall-Salvati ratio [11] & $0.8-1.2$ & $1.09 \pm 0.17(0.49-1.60)$ \\
Caton-Deschamps index [12] & $0.6-1.3$ & $0.97 \pm 0.16(0.62-1.64)$ \\
Trochlear Angle [13] & $135^{\circ} \pm 10$ & $138.97 \pm 119.7(122-160)$ \\
Lateral trochlear inclination [14] & $>11^{\circ}$ & $20.37 \pm 4.56(11.0-30.6)$ \\
TT-TG distance [13] & $12.7 \pm 3.4$ & $13.76 \pm 5.86(4.9-41)$ \\
Trochlear depth [13,15] & $>3$ & $5.18 \pm 1.87(1.05-8.6)$ \\
\hline SD: Standard deviation & &
\end{tabular}

In patellofemoral study, there were several aspects that have been adjusted to Indonesian values and characters such as the Indonesian version of the Kujala [20]. Some countries also adapted, validated and translated the scales in accordance with their language including Chinese, Persian, Turkish, Thai, and German [20]. However, some parameters of patellofemoral measurements from the Indonesian people have not been investigated yet.

Table 4: Comparison of males' and females' patellofemoral values

\begin{tabular}{|c|c|c|c|c|}
\hline Parameters & $\begin{array}{l}\text { Males } \\
\text { (Mean } \pm \mathrm{SD} \text {, } \\
\text { Range) }\end{array}$ & $\begin{array}{l}\text { Females } \\
\text { (Mean } \pm \text { SD, } \\
\text { Range) }\end{array}$ & $95 \% \mathrm{Cl}$ & $p$ value \\
\hline Insall-Salvati ratio & $\begin{array}{l}1.09 \pm 0.17 \\
(0.49-1.60)\end{array}$ & $\begin{array}{l}1.09 \pm 0.18 \\
(0.49-1.60)\end{array}$ & $-0.77-0.67$ & 0.89 \\
\hline Caton-Deschamps index & $\begin{array}{l}0.97 \pm 0.16 \\
(0.62-1.64)\end{array}$ & $\begin{array}{l}0.97 \pm 0.16 \\
(0.62-1.64)\end{array}$ & $-0.06-0.06$ & 0.94 \\
\hline Trochlear angle & $\begin{array}{l}139.04 \pm 7.02 \\
(123-160)\end{array}$ & $\begin{array}{l}138.44 \pm 7.45 \\
(122-160)\end{array}$ & $-3.01-3.66$ & 0.84 \\
\hline $\begin{array}{l}\text { Lateral trochlear } \\
\text { inclination }\end{array}$ & $\begin{array}{l}20.20 \pm 4.54 \\
(11-30)\end{array}$ & $\begin{array}{l}20.57 \pm 4.62 \\
(11.3-30.6)\end{array}$ & $-2.27-1.52$ & 0.69 \\
\hline TT-TG distance & $\begin{array}{l}13.57 \pm 5.95 \\
(4.9-41)\end{array}$ & $\begin{array}{l}13.99 \pm 5.81 \\
(5-41)\end{array}$ & $-2.67-2.15$ & 0.82 \\
\hline Trochlear depth & $\begin{array}{l}5.15 \pm 1.83 \\
(1.05-8.60)\end{array}$ & $\begin{array}{l}5.22 \pm 1.94 \\
(1.05-8.60)\end{array}$ & $-0.92-0.68$ & 0.76 \\
\hline
\end{tabular}

Based on the 2010 population census, the composition of the majority of Indonesia's population is Javanese $(41.71 \%)$, Sundanese $(15.41 \%)$, Madura 
(3.37\%), and Minangkabau (2.72\%) [21], almost the same with our study, that had most of subjects from Javanese (66\%), Sundanese (12\%), and Minangkabau $(7 \%)$ ethnicity.

Table 5: Comparison with other studies

\begin{tabular}{|c|c|c|c|c|c|}
\hline & $\begin{array}{l}\text { Alemparte } \\
\text { et al. [16] }\end{array}$ & $\begin{array}{l}\text { Song } \\
\text { et al. } \\
\text { [17] }\end{array}$ & $\begin{array}{l}\text { De Jour } \\
\text { et al. [18] }\end{array}$ & $\begin{array}{l}\text { Raja } \\
\text { et al. [19] }\end{array}$ & Our Study \\
\hline Place of study & Chile & Korea & France & India & Indonesia \\
\hline Method & CT Scan & CT Scan & CT Scan & CT Scan & MRI \\
\hline Number of knees & 60 & 100 & 100 & 67 & 100 \\
\hline TT-TG & 13.6 & 10.24 & 12.7 & 13.1 & 13.76 \\
\hline TT-TG standard deviation & 8.8 & 0.8 & 3.4 & 2.84 & 5.86 \\
\hline
\end{tabular}

Patellar height of Indonesian people according

to the Insall-Salvati ratio and the Caton-Deschamps was $1.09 \pm 0.17$ and $0.97 \pm 0.16$, respectively. These values were within the range of the normal international values. The trochlear angle of the patients assessed in this study $138.97^{\circ} \pm 119.7$ was within the normal value. The lateral trochlear inclination assessed in this study $20.37 \pm 4.56$ was within the normal value $\left(>11^{\circ}\right)$ but mostly in the very high value. TT-TG and the trochlear depth of the patients assessed in this study 13.76 \pm 5.86 and $5.18 \pm 1.87$, respectively, were within the normal values.

Previous study that measured TT-TG in normal Indian population using computed tomography (CT) of knees showed result $13.01 \mathrm{~mm}$, which was not different between males and females and was similar to the Western population but this result was lower than our study [19]. In Korea, Song et al. reported the value of TT-TG Korean people of $10.24 \pm 0.8 \mathrm{~mm}$, which was lower than our study [17]. Other study in Chile by Alemparte et al., using CT scan, reported the mean Insall-Salvati and Caton-Deschamps indexes were $1.09 \pm 0.24$ and $0.95 \pm 0.29$, respectively. These results were a similar with our finding in Indonesian people $(1.09 \pm 0.17$ and $0.97 \pm 0.16$, respectively) (16). Other parameters that Alemparte et al. investigated were sulcus angle and TT-TG values of $139.7 \pm 20.4$ and $13.6 \pm 8.8 \mathrm{~mm}$, respectively, which were similar with our study $\left(138.97^{\circ} \pm 119.7\right.$ and $\left.13.76 \pm 5.86\right)$ [16]. In the study conducted by Dejour et al., the mean TT-TG distance for the control group was $12.7 \pm 3.4 \mathrm{~mm}$ and the mean TT-TG distance for the patellar instability group was $19.8 \pm 1.6 \mathrm{~mm}$, while $20 \mathrm{~mm}$ was determined as the cutoff value for patellar instability [13].

All of those parameter measurements were used to detect whether there was any patellar dysplasia or not [9], [14], [15]. The research conducted by Resorlu et al. found that any abnormalities in those trochlear morphological values influence chondromalacia in the patella [22]

Hsu et al. showed that gender plays a role in trochlear morphology, specifically male trochlear generally have greater height and width compared to females. This phenomenon was also reflected in our study that showed the male group has bigger values in trochlear depth and angle. However, these differences were not able to be evaluated statistically [22].

\section{Conclusions}

The means of Insall-Salvati ratio, CatonDeschamps index, trochlear angle, lateral trochlear inclination, and TT-TG trochlear depth of the Indonesian people were within the international normal range, and higher than other countries' published measurements.

\section{Acknowledgments}

We thank the staff of Klinik Bahasa for their help during manuscript preparation.

\section{References}

1. Purohit N, Hancock N, Saifuddin A. Surgical management of patellofemoral instability. I. Imaging considerations. Skeletal Radiol. 2019;48(6):859-69. https://doi.org/10.1007/ s00256-018-3123-1

PMid:30542758

2. Yu Z, Yao J, Wang X, Xin X, Zhang K, Cai H, et al. Research methods and progress of patellofemoral joint kinematics: $A$ review. J Healthc Eng. 2019;2019:9159267.

PMid:31019669

3. Loudon JK. Biomechanics and pathomechanics of the patellofemoral joint. Int J Sports Phys Ther. 2016;11(6):820-30. PMid:27904787

4. Collado $\mathrm{H}$, Fredericson $\mathrm{M}$. Patellofemoral pain syndrome. Clin Sports Med. 2010;29(3):379-98

PMid:20610028

5. Luyckx T, Didden K, Vandenneucker H, Labey L, Innocenti B, Bellemans $\mathrm{J}$. Is there a biomechanical explanation for anterior knee pain in patients with patella alta?: Influence of patellar height on patellofemoral contact force, contact area and contact pressure. J Bone Joint Surg Br. 2009;91(3):344-50. https://doi. org/10.1302/0301-620x.91b3.21592

PMid:19258610

6. Tanaka MJ, Cosgarea AJ. Measuring malalignment on imaging in the treatment of patellofemoral instability. Am J Orthop (Belle Mead NJ). 2017;46(3):148-51

PMid:28666038

7. Escala JS, Mellado JM, Olona M, Giné J, Saurí A, Neyret P Objective patellar instability: MR-based quantitative assessment of potentially associated anatomical features. Knee Surg Sports Traumatol Arthrosc. 2006;14(3):264-72. https://doi.org/10.1007/ s00167-005-0668-z

PMid:16133440

8. Elias DA, White LM. Imaging of patellofemoral disorders. Clin Radiol. 2004;59(7):543-57.

PMid:15208060

9. Macri EM, Felson DT, Zhang Y, Guermazi A, Roemer FW, Crossley KM, et al. Patellofemoral morphology and alignment: Reference values and dose-response patterns for the relation to MRI features of patellofemoral osteoarthritis. Osteoarthritis 
Cartilage. 2017;25(10):1690-7. https://doi.org/10.1016/j. joca.2017.06.005

PMid:28648740

10. Endo $Y$, Stein BE, Potter HG. Radiologic assessment of patellofemoral pain in the athlete. Sports Health. 2011;3(2):195210. https://doi.org/10.1177/1941738110397875 PMid:23016009

11. Verhulst FV, van Sambeeck JD, Olthuis GS, van der Ree J. Patellar height measurements: Insall-salvati ratio is most reliable method. Knee Surg Sports Traumatol Arthrosc. 2020;28(3):86975. https://doi.org/10.1007/s00167-019-05531-1

PMid:31089790

12. Narkbunnam R, Chareancholvanich K. Effect of patient position on measurement of patellar height ratio. Arch Orthop Trauma Surg. 2015;135(8):1151-6. https://doi.org/10.1007/ s00402-015-2268-9

PMid:26138208

13. Dejour H, Walch G, Nove-Josserand L, Guier C. Factors of patellar instability: An anatomic radiographic study. Knee Surg Sports Traumatol Arthrosc. 1994;2(1):19-26. https://doi. org/10.1007/bf01552649

PMid:7584171

14. Carrillon Y, Abidi H, Dejour D, Fantino O, Moyen B, van TranMinh A. Patellar instability: Assessment on MR images by measuring the lateral trochlear inclination-initial experience. Radiology. 2000;216(2):582-5. https://doi.org/10.1148/ radiology.216.2.r00au07582

PMid:10924589

15. Pfirrmann CW, Zanetti M, Romero J, Hodler J. Femoral trochlear dysplasia: MR findings. Radiology. 2000;216(3):858-64. https:// doi.org/10.1148/radiology.216.3.r00se38858 PMid:10966723

16. Alemparte J, Ekdahl M, Burnier L, Cardemil A, Cielo R, Danilla S, et al. Patellofemoral evaluation with radiographs and computed tomography scans in 60 knees of asymptomatic subjects. Arthroscopy. 2007;23(2):170-7. https://doi.org/10.1016/j. arthro.2006.08.022

PMid: 17276225

17. Song EK, Seon JK, Kim MC, Seol Y, Lee SH. Radiologic measurement of tibial tuberosity-trochlear groove (TT-TG) distance by lower extremity rotational profile computed tomography in Koreans. Clin Orthop Surg. 2016;8(1):45-8. https://doi.org/10.4055/cios.2016.8.1.45

PMid:26929798

18. Raja BS, Mohan H, Jain AM, Gautham S. Computed tomography-based analysis of tibial tuberosity-trochlear groove distance in Indian population. Cureus. 2019;11(7):e5277. https:// doi.org/10.7759/cureus.5277

PMid:31576269

19. Mustamsir E, Phatama KY, Pratianto A, Abduh M, Hidayat M. Validity and reliability of the Indonesian version of the Kujala score for patients with patellofemoral pain syndrome. Orthop J Sports Med. 2019;8(5):1-5. https://doi.org/10.1177/2325967120922943 PMid:32523969

20. Joko A, Triwahyudi $H$. Dinamika perkembangan etnis $d i$ Indonesia dalam konteks persatuan negara. Populasi. 2017;25(1):64-81. https://doi.org/10.22146/jp.32416

21. Resorlu H, Zateri C, Nusran G, Goksel F, Aylanc N. The relation between chondromalacia patella and meniscal tear and the sulcus angle/trochlear depth ratio as a powerful predictor. $J$ Back Musculoskelet Rehabil. 2017;30(3):603-8. https://doi. org/10.3233/bmr-160536

\section{PMid:27911285}

22. Hsu CP, Lee PY, Wei HW, Lin SC, Lu YC, Lin JC, et al. Gender differences in femoral trochlea morphology. Knee Surg Sports Traumatol Arthrosc. 2020;2020:1-10. https://doi.org/10.1007/ s00167-020-05944-3

PMid:32232538 